\title{
8
}

\section{Triggering the 'Second Part': Old School Patterns, a New Bindoon Community and Visiting the Villages Again}

In the Notebooks kept and edited by the Benedictine Missionary Sisters, the end of 1948 began the 'Second Part' of their history. A confident narrator announced a refounding after all that had gone before. Behind that new beginning, and important for understanding it, lay the foundation of another house at Bindoon and the continuing hope for a bigger, younger community. If the late 1930s and 1940s at New Norcia were marked by continuity or even stasis as buildings aged and the community tired, the verve of the newcomers challenged assumptions, setting the scene for change.

\section{'Our Sisters may go to Bindoon'}

Even before the party of 12 postulants arrived at New Norcia in 1948, it was clear that the branch house at Bindoon would demand more ablebodied workers than the congregation had to spare. The monastery had been under pressure from a powerful Catholic lobby in Perth to support the Christian Brothers at Bindoon in what seemed at the time to be a flagship innovation in social welfare and Catholic immigration. Now, after allegations in the late 1980s began a long process of former residents 
seeking justice and healing, the Bindoon Farm School, at the heart of 'the scheme' to bring British boys to Western Australia, is a focus within Case Study 11 of the Royal Commission into Institutional Responses to Child Sexual Abuse. The statue of the founder who pressed New Norcia for help has been removed at the request of former residents who suffered at his hands and those of 15 other men on the staff. ${ }^{1}$ But in postwar Perth, Bindoon was lauded as a social justice innovation that would see boys in need trained as farmers and given land. It echoed the hopes that the mission's founder, Rosendo Salvado, had held for Aboriginal men at New Norcia in the 1860 s.

In March 1948, however, New Norcia saw Bindoon as a large Catholic development on the Benedictine doorstep and something of a risk to the monastery's independence. When Bindoon's founder, Brother Keaney, called with a senator and four 'big men' (prohombres), ${ }^{2}$ influential backers of the scheme in Perth, to put their case for domestic help, Abbot Catalan knew he did not have enough sisters to establish another branch house, not really: 'How are we going to charge our Sisters with more work when they are so few?' he asked his prior, Fr Wilfrid Saenz, in January 1948. 'Maybe when we have professed some of the postulants I am bringing with me, God willing, [but] there will be great difficulties if we try to increase the work without increasing the number of Sisters'. ${ }^{3}$ While he could see the Benedictine women would be overstretched, he knew some other group would accept the invitation if he refused. Preserving the Benedictine character of the missionary work and his diocese had prompted other decisions on behalf of the missionary women in the past, and now Catalan observed to his prior that if we let other Sisters into Bindoon nobody will remove them'. ${ }^{4}$ It could not be a matter of waiting until numbers were healthier.

1 Royal Commission into Institutional Responses into Child Sexual Abuse, Report of Case Study Number 11, Congregation of the Christian Brothers in Western Australia Response to Child Sexual Abuse at Castledare Junior Orphanage, St Vincent's Orphanage Clontarf, St Mary's Agricultural School and Bindoon Farm School, (Sydney: Commonwealth of Australia, December 2014).

2 Abbot Catalan to Fr Wildrid Saenz, 17 March 1948, New Norcia Archives (NNA) 01451/15.

3 Catalan to Saenz, 19 January 1948, NNA 01451/18.

4 Catalan to Saenz, 17 March 1948. 
After some two months of deliberation, during which Sr Felicitas also led him to think that 'they will all like to have this new foundation', ${ }^{5}$ Catalan sent a cablegram to the Christian Brothers announcing, 'Our Sisters may go to Bindoon'. ${ }^{6}$ The way forward would be 'based on a number of girls living with the Sisters' ${ }^{7}$ and sharing in the work. The work was apparently to be done on the same basis as at New Norcia and Kalumburu, with no separate payment to the monastery, the sisters or the Aboriginal women involved, beyond the food and lodging of the workers. Unsurprisingly, this is one of the causes of deep resentment against both Bindoon and New Norcia among some of the Aboriginal women and one of the issues raised regularly in conversations about the need for reconciliation and healing. The sisters are also frank about the level of exhaustion they experienced at Bindoon. Their community was responsible for the domestic support of the institution that included 12 Christian Brothers and almost 100 boys.

At the time, there was no discussion of conditions or remuneration. The abbot did, however, extract a candid promise from the Brothers to provide and pay for new washing machines. 'Have you still not asked?', he prompted his prior, urging him not to hesitate as prospects seemed bright, 'With the price of wool there's money, right?'8 Sr Felicitas sent the clipping from the Record announcing the new foundation. ${ }^{9}$ The abbot commented to Fr Ubach, 'Brother Keaney must be over the moon content to have achieved what they so earnestly desired'. ${ }^{10}$ In marked contrast with the opening of the house at Drysdale River more than 25 years earlier, there was no satisfaction on his own account but rather foreboding at stretching the resources so thinly.

On 19 March 1948, appropriately the feast day of St Joseph, the sisters took possession of a pleasant, purpose-built convent they shared with the Aboriginal girls rostered to help. On 14 April there was High Mass in the chapel at Bindoon, followed by the formal blessing of the convent building. ${ }^{11}$ Sr Benita and Sr Francisca were the steady founding members of the house. Benita, now 41, had been superior at New Norcia after her experience in Belgium. She had a reputation for being strict and unyielding

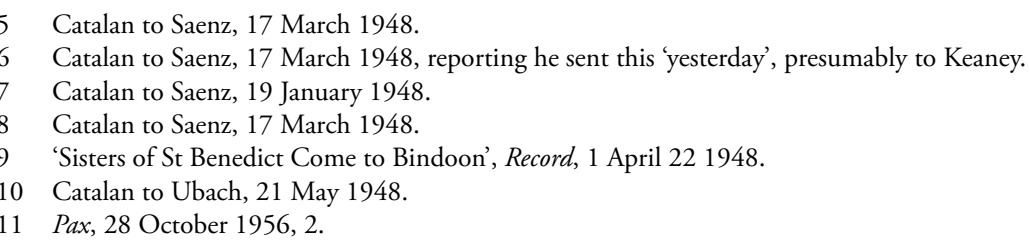


with the girls, especially as nurse in charge of treatment for stone bruises on bare feet; her hallmark method of discipline was to pull a child into line by the earlobe. Severe and sincere, she was not a lateral thinker, but she was practical and dedicated. Francisca was 30 years old and already had the reputation for amenable adaptability and kindheartedness that would see perplexed superiors request her presence in a community when there were tensions: 'If she will not be sympathetic ... send Francisca only on this occasion'. And still decades later: 'The time has come for Sr Francisca to return'. ${ }^{12}$ Both sisters were hard workers, good plain cooks, ready to mend and make clothes.

Sharing the household with the sisters until the postulants were ready to take their place on the rosters were Rosie Finucane, Pearl Cameron and Phillis Stack. Rosie brought more experience than either of the sisters: now 52, she had first been admitted to St Joseph's in 1899. She had worked alongside Grace Williams with Maria Harispe and Teresa Roca and had returned in 1941 after an unknown number of years away. ${ }^{13}$ Pearl and Phillis, 15 and 13 years old, respectively, ${ }^{14}$ were also known as trustworthy and competent and similarly brought skills to the laundry, sewing room and kitchen. The next year, Vera Farrell, also steady and capable at 13 years of age, came to share the workload. The photograph of the community on the steps of the college echoes images from the turn of the century: Aboriginal and Spanish workers together outside a grand institution.

The Spanish Notebooks rang a familiar note: 'Hard were the beginnings and great the sacrifices of the first Sisters. Also at New Norcia the sisters were overwhelmed by ongoing work that was enough, and more than enough'. ${ }^{15}$ In the six months before the new recruits arrived from Spain, a community of six (or five workers, allowing for Teresa Roca's age and arthritis) kept New Norcia running, while two sisters continued in the Kimberley and two established Bindoon.

12 Catalan to Wilfrid Saenz re Kalumburu, 19 January 1948, NNA 01458; Seraphim Sanz to Mary, 1970, Archives of the Benedictine Missionary Sisters of Tutzing (ABTM).

13 Peter Hocking, New Norcia, personal communication, 15 February 2016; 'New Norcia Mission Subsidy and General', State Records Office of Western Australia (SROWA) S2030 cons993 1926/0350, 31 December 1917, 31 December 1918.

14 Aboriginal Families Index (NNA), Peter Hocking, New Norcia, personal communication, 21 January 2016.

15 'Origen de la Congrecacion de las Hermanas Benedictinas Misioneras de New Norcia, Western Australia' unpublished typescript from the notebooks of Sister Felicitas Pampliega c. 1921-c. 1967, transcribed and edited by Sister Teresa González, Madrid c. 1980, Archives of the Benedictine Missionary Sisters of Tutzing (ABTM) (hereafter Notebooks, Madrid), 22. 


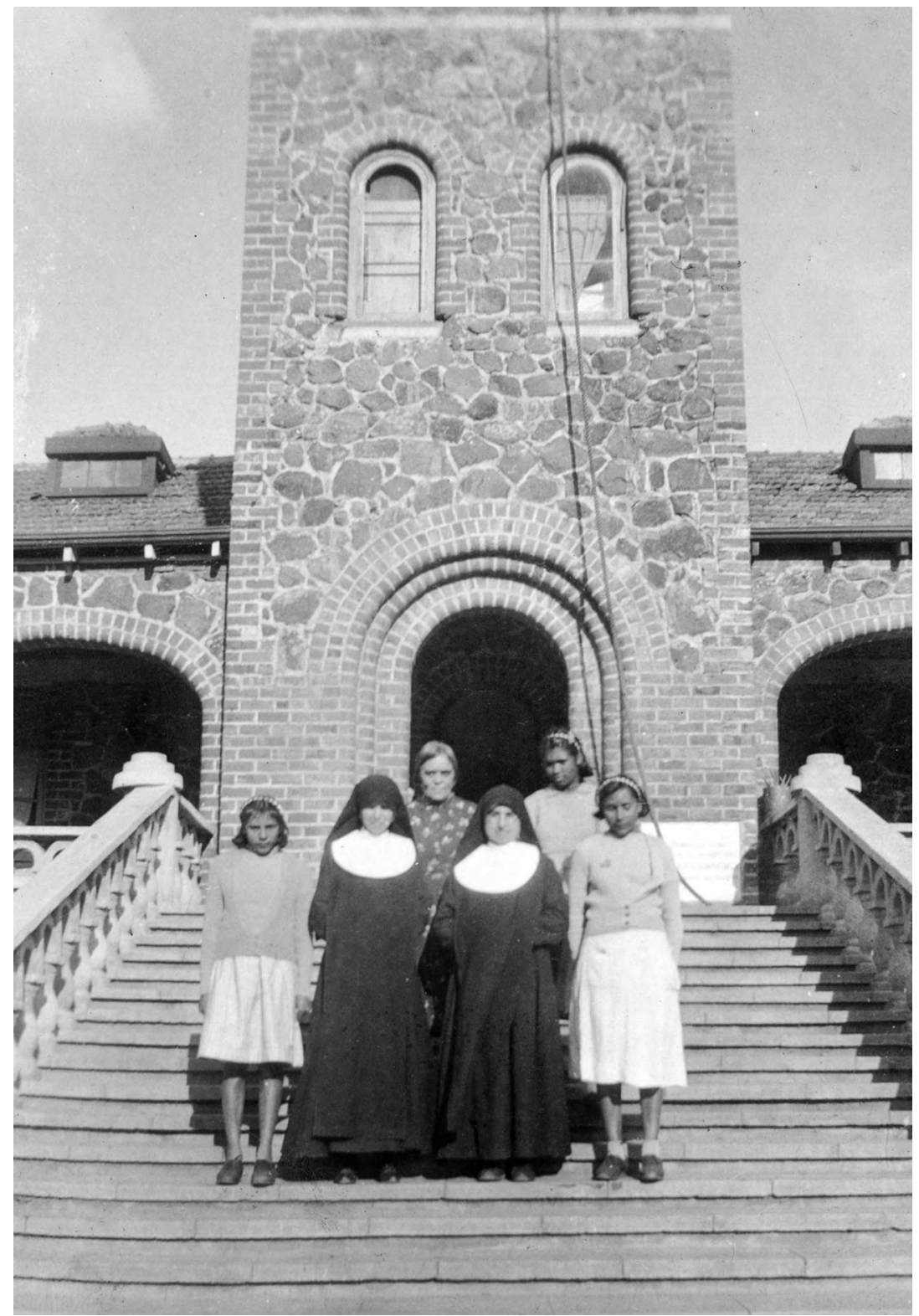

Figure 8.1: First Community at Bindoon, c. 1949.

Source: ABTM. 


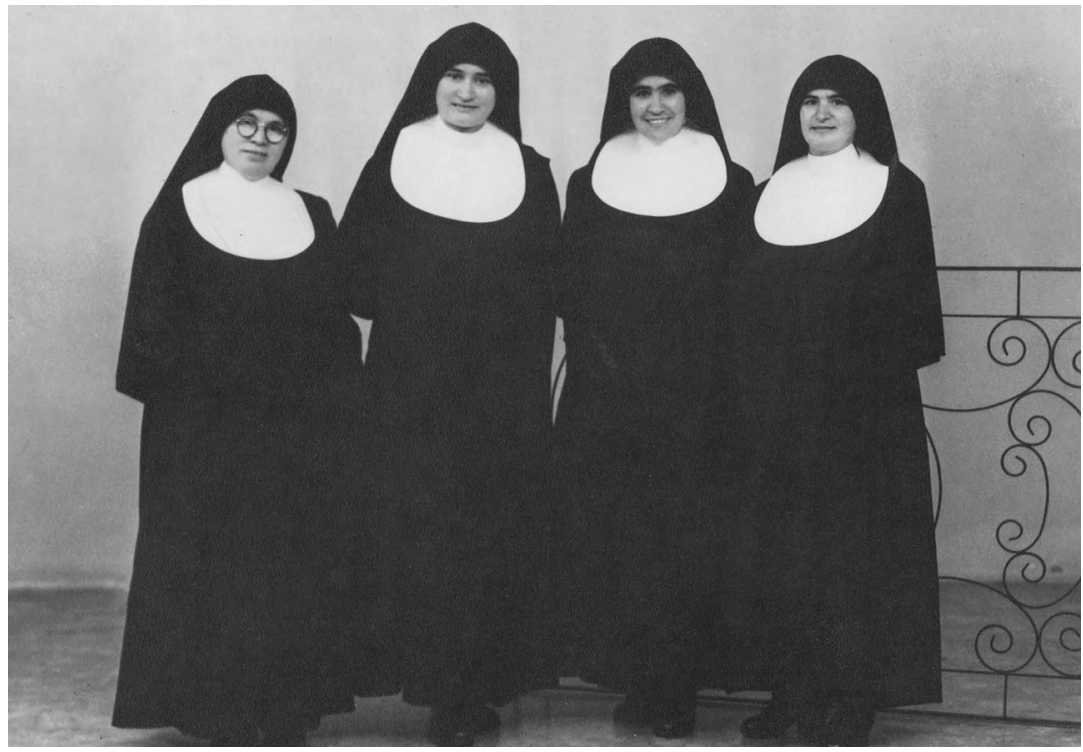

Figure 8.2: A studio portrait to send to their families was a thank-you gift to the Benedictine sisters at Bindoon in the 1950s (Hildegard, Visitación, Florentina and Lucia).

Source: ABTM.

The first community at Bindoon followed the patterns of work at New Norcia but more intensely. There were two sisters with limited English running the domestic arrangements for a busy institution, assisted by older Aboriginal women who had trained at New Norcia too. The rosters were more rigorous because the tasks in the bigger institution were shared among fewer women. The conditions were demanding, even for women used to hard domestic work. Francisca recalled, 'Ah! At first! Ah! We did not know how to manage. ${ }^{16}$ The badly nourished boys she saw on her arrival shocked her; they seemed much worse off than the Aboriginal people:

Paubre, poor things, poor things! And some of them had no hair at all. Brother Keaney said to give them lots of honey. Honey, always honey. And at first we used to peel the apples and put the scraps in the bin, and they would go for that, because that was how it had been when they were starving. ${ }^{17}$

16 Francisca Pardo, Interview, Madrid, 4 June 1999.

17 Francisca Pardo, Interview, Madrid, 4 June 1999. 
On evidence of the residents, they still were starving. ${ }^{18}$ But Francisca remembered improvement and progress: 'After a few months-oh different boys. They had a lot of cows there so always plenty of milk, and honey from the boxes'. ${ }^{19}$ Did they see anything, hear anything that seemed wrong? 'About?' Francisca asks. I clarify: 'About the boys being treated badly'. 'No, no I didn't hear anything about that. ${ }^{20}$ They saw the boys who were rostered to help in the kitchen and serve in the dining room but had little interaction with them. The royal commission remarks on the Spanish sisters' lack of English and speculates that a stronger feminine presence in the institution might have helped. ${ }^{21}$ The Benedictine Missionary Sisters interacted even less with the Christian Brothers. The work overwhelmed all:

Sometimes [the brother in charge] was sorry we were working so hard, and he would say to us: 'You Sisters are working very hard, no time for prayer, no time for anything. You must come and see a picture with us.' Because, you know, they had films on Saturdays. He would tell us it would be Our Lady of Fatima or The Story of the Little Flower and I would think, 'ahhhb'.

Francisca sighs and opens her hands in a gesture of helpless regret, 'I did not want to go'. ${ }^{22} \mathrm{~A}$ film in English, even a religious film, was just another pressure when there was so much to do and rest was so rare.

When the postulants arrived they were rostered through Bindoon to help with the volume of urgent sewing as well as other tasks. 'They put me in the tower', Scholastica Carrillo remembers:

and out of big military garments I was making smaller garments for the migrant boys. I didn't know any English and I was all day sewing and cutting and sewing and cutting. ... I think they did stop [for prayers], but I was a postulant, so not really bound by them. So I was in the tower, sewing and cutting. ${ }^{23}$

18 For example, Royal Commision, Report of Case Study Number 11, Transcript, WA15: 1694; on the role of the Benedictine sisters, Transcript, Day WA14: WA1620, WA1621; Day WA15: WA1705; Day WA19: WA2136.

19 Francisca Pardo, Interview, Madrid, 4 June 1999.

20 Francisca Pardo, Interview, Madrid, 4 June 1999.

21 Royal Commision, Report of Case Study Number 11, Transcript, Day WA19: WA2136.

22 Francisca Pardo, Interview, Madrid, 4 June 1999.

23 Scholastica Carrillo, Interview, Madrid, 7 June 1999. 
But it was clear that the community needed more workers. Mary Cidad, newly appointed as novice mistress, was emerging as a strong advocate among the sisters; she wanted to see branch houses with the canonical six members, not fewer. Everyone agreed that two in a house was not enough. Francisca was needed at Drysdale River to make three there. Hildegard replaced her at Bindoon, leaving only four professed sisters at New Norcia.

Less than two weeks after the 12 postulants made their formal commitment to the Benedictine community as novices on 1 July 1949, Abbot Catalan embarked again for Europe with letters from the Immigration Department to enable him to bring more young women to the mission. The newcomers would be drawn into a heritage of 40 years of convent life at New Norcia, as well as into another round of negotiation between the sisters and the wider church about the collective identity of the missionary women.

\section{Recruiting, again: 'The strongest vocations, best suited to the circumstances'}

In July 1949 Fr Tubau took a photograph of the novices, nervously telling them they could burn it if they did not want to keep it. ${ }^{24}$ 'It seems they all must have liked it', Abbot Catalan reassured Tubau from Spain in September. As he travelled around the villages of Burgos he found that photograph circulating too: 'I don't know of any who did not send it to her family'. ${ }^{25}$ Sister Felicitas sent the abbot another copy, and he likewise showed it around 'with much pride', ${ }^{26}$ promoting New Norcia as a place where the village girls were 'getting fat ${ }^{27}$ and flourishing. He told Felicitas that 'all who see them and know the young people are amazed at seeing them so full of health'. ${ }^{28}$ For families in Spain's 'hungry years', a daughter gaining weight was a definite bonus to her missionary vocation.

The abbot took every opportunity to emphasise that the group was thriving. When he unexpectedly passed through Marie-Therese's home town of Villaquirán, he and his prior, Fr Wilfrid, took the opportunity to speak to a crowd of young women at the train station, hoping these

24 Catalan to Tubau, recalling this, 4 December 1949, NNA 01454/43.

25 Catalan to Tubau, 4 December 1949.

26 Catalan to Felicitas, 12 September 1949, NNA 01454/128.

27 Catalan to Vistación, February 1949.

28 Catalan to Felicitas, 12 September 1949. 
locals knew her. They were in luck. The monks asked the girls specifically 'to inform the family that Sr Marie-Therese had stayed in Australia full of health and satisfaction'. ${ }^{29}$ The friends promised to give the messages. The abbot was keen to reassure, but did he protest too much?

There had been some disquiet in the network of New Norcia families in the north of Spain, so the abbot was also armed with a letter from Sr Felicitas, 'To Whom It May Concern', defending him against charges of neglecting the community of missionary women. She referred to 'one or other of our religious, carried away by exaggerated zeal', ${ }^{30}$ who may have been unhappy that the constitutions from Maredsous had been modified and to 'some Sister disgruntled because the Superioress [sic] was not appointed by election', ${ }^{31}$ and she answered both complaints. The constitutions would soon be ready, and she wrote as the elected, not appointed, 'Prioress General' of the group. She assured readers the abbot provided 'everything'. She emphasised his spiritual oversight in particular. The monastery ensured they had confessors, celebrants for daily Mass, a chapel with the Sacrament, regular preaching, and now, with so many new novices, a reinstituted weekly conference. While the letter aimed to quell any anxiety about the status of the community and its integration into the monastic town, the simple fact that there was apparently a need to write it invites interpretation.

Although Felicitas meant what she said, when we read her testimonial in light of another letter she had written earlier in the year, preserved not at New Norcia but in the archives of the sisters in Madrid, it is clear that the nagging issue of the status of the community was still not resolved.

\section{Waiting for the constitutions}

Sister Felicitas had drafted constitutions for New Norcia's missionary sisters soon after her return from Belgium in 1936, using the documents of the Benedictine Sisters of Mercy of Heverlé in Maredsous as a template, but after 13 years they had not been confirmed. In January 1949 Felicitas lost patience with Abbot Catalan's delays. She wrote a frank letter threatening him with the community's 'discouragement' and loss of 'vigour' if he did

29 Catalan to Felicitas, 12 September 1949.

30 Felicitas, 'To Whom It May Concern', 10 July 1949, trans. Fr David Barry, OSB, NNA 01451/196.

31 Felicitas, 'To Whom It May Concern', 10 July 1949. 
not attend to the legalities of the group that had just accepted an influx of new members. There was none of the deferential girlishness that marked so many of the sisters' letters to their abbot. She argued that her work did not need further review. It is hard to imagine that the monks would have tolerated confusion about their own constitutions for so long. In any case, the men would not have been dependent on another community for a decision.

Felicitas was a leader under pressure. She was less dynamic than Mary, less authoritative than Benita. The power struggle between the three was obvious to the novices. Magdalena was steadier and more perceptive but had hardly grasped English and excluded herself from the leadership battle except as a counsellor to Felicitas. The younger sisters felt that Felicitas 'did not think about the overall good of the situation'. ${ }^{32}$ She has critics among the past students too: 'She had favourites among the girls and she was always for the underdog. If you had parents she was not for you'. ${ }^{33}$ Emotion could cloud her judgement and some memories are bitter. She would 'take over' for 'her' girls, judging parents harshly and dismissing their claims for access on the grounds their daughters were 'better off without them'. ${ }^{34}$ There was no questioning her commitment though, even when her benevolence was so misdirected: 'She was a very good person. She loved the girls, the natives, very much and wanted them to have everything they wanted. But she was not very strong, not very forceful'. ${ }^{35}$ She valued a strong institution.

The unresolved constitutions weighed on Felicitas, but she could not end the impasse. If Abbot Catalan responded to her at all it was not in any way that left a documentary trace. The constitutions do not surface again directly in the sources at New Norcia. The archives of the sisters in Madrid, however, reveal that the formal confirmation was signed six years later by Catalan's successor, Abbot Gregory Gomez, on 22 August 1954. The sisters were told he affirmed the document 'gladly' and urged them to observe it 'solicitously and faithfully'. ${ }^{36}$

32 Teresa González, Interview, Madrid, 27 May 1999.

33 Veronica Willaway, Interview, Nebraska, 7 July 2012.

34 Sheila Humphreys in conversation, New Norcia, May 1999.

35 Teresa González, Interview, Madrid, 27 May 1999.

36 Gomez to Felicitas, 22 August 1954, ABTM. 
Was it only the pressure of other things, including his own ill health, that kept Anselm Catalan from signing off on the foundation he had aimed at since 1921 and acted to establish in 1933, or was he actively withholding approval of something in the constitutions - something that Gregory Gomez was more willing to slide over? It seems the negotiation was around the familiar fault line of how (or whether) the sisters would manage a life that was both monastic and missionary. The changes Felicitas made in her translation of the Maresdous material, and then the variations that were finally approved, are explored in the final chapter. ${ }^{37}$ For now, it is enough to note they all point to a community still struggling to fit its collective vocation into a recognisable framework.

No wonder, then, that Abbot Catalan thought he might need a pre-emptive 'To Whom It May Concern' in 1949. There was in fact a significant gap in the status of his diocesan community. As it turned out, however, apparently no one thought to press the point. Instead, he found more willing applicants than he had permission from Australian immigration to bring. ' $[T]$ his is better for me', Catalan observed as he asked a colleague to assess the candidates in the neighbouring province, 'as I can choose the strongest vocation and those who suit other circumstances best. ${ }^{38}$

Four candidates were already waiting, all with ties to the group: Visitación Cidad had been born in the year her aunt Sr Hildegard went to the Kimberley and was cousin to two others in the group of 12, all from Tapia Villadiego. From the same village, Clementina Vallejo had been too young to travel with her older brother, Jésus, when he left with the group in 1948, but now she was 15, tall, mature for her years, and still keen. At 16 Julia Rubio from Sotopalacios was joining her sister Josefa, now the new Sister Edita. Twenty-one-year-old Maria Villaño, born and raised in Burgos, worked for a family in San Sebastian where she had known Josefina Carrillo, the new Sister Scholastica. The abbot also accepted two from the historic hamlet of Callohora, near Fr Wilfrid's home town: Maria Carmen Ruiz Besti, 26, who had found Australia could replace her dream of missionary work in China now that those borders were closed, and 15-year-old Ines Herce, who had been training as a seamstress. ${ }^{39}$ On 6 March 1950 they arrived at New Norcia.

37 See Chapter 10.

38 Catalan to P. Valero Lopez, OSA, 9 September 1949, NNA 01454/21.

39 Carmen Ruiz Besti, with Sr Hilda Scott and Katharine Massam, Interview, New Norcia, 28 July 1999. 


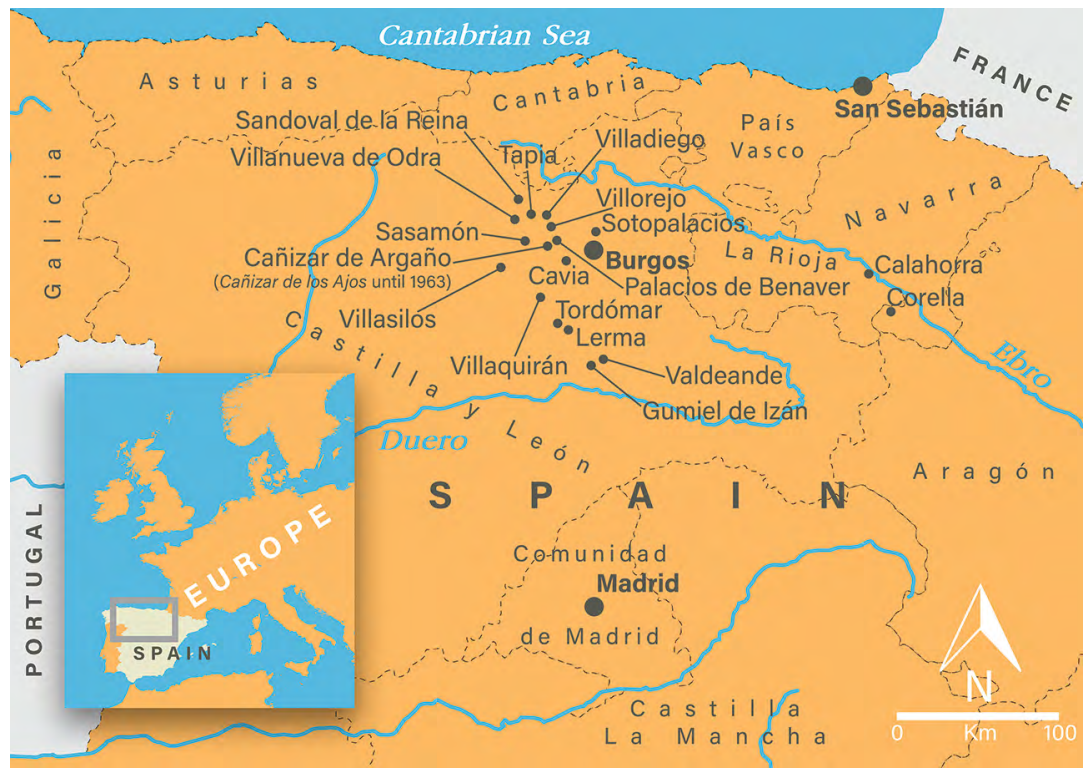

Figure 8.3: Home villages of the Benedictine sisters to 1950, still focused on Burgos.

Source: Map by Alejandro Polanco Masa.

If this recruiting journey seemed a simpler process, with awareness of New Norcia high in the wake of the 1948 departures, there was still plenty of drama, and perhaps none so telling as the tension the abbot provoked in the Cidad family during his visit to Tapia. The abbot's letter to Sr Hildegard, describing his confrontation with her sister Crispina, casts light on the place of New Norcia in the spiritual landscape, as well as taking us close to the dynamics of recruiting. Hildegard's own letters to her family played a role in the eventual decision too, we know, but the only account that has survived is the abbot's report, perhaps as close as he ever came to debriefing.

\section{Tapia, 1949}

Abbot Catalan's visit to Tapia late in 1949 had not been announced, 'but I had not been there two minutes when all the families interested in my visit were in commotion'. ${ }^{40}$ The Vallejo, Ruiz, Arroyo, Amo and de la Fuente families already with sons and daughters at New Norcia all flocked

40 Catalan to Hildegard, 14 December 1949, NNA 01454/131. 
to the parish house, determined to greet the distinguished guest. But not Crispina Cidad, 'not at all', the abbot wrote to Hildegard. ${ }^{41}$ Instead, 'What did your sister do? Immediately, she went to do the washing in a neighbouring village and did not return until nightfall'. ${ }^{42}$ Her daughter, Visitación, had always wanted to be a nun, and she had been interested in New Norcia for years. Her aunt had sent her photos. She had wanted to go last time, but her parents refused permission. Visitación had written to greet the abbot for his feast day earlier in the year and received a gracious reply telling her about the new novices, all well and happy and 'fattening up. ${ }^{43} \mathrm{He}$ noted pointedly that it was 'too bad that instead of sending me this [holy card of a] dove to bring these good wishes you had not come yourself, as you wanted to when I was there. ${ }^{44}$ Now he had returned and he knew Crispina 'feared ... Visitacion would insist again that she wants to be a missionary in Australia'. ${ }^{45}$ Crispina would not join the festive welcome to the recruiting abbot. Laundry in another place was a responsibility that better suited her mood.

Visitación took the initiative. She was 'most animated in carrying out her project'. ${ }^{46}$ Her father, Gregorio, and her older brother were persuaded that her wish to be a Benedictine missionary was the will of God. The day passed. Her mother returned. The Cidad family still did not call on the abbot, but well after sundown Visitación came with her father and two youngest sisters. The abbot suggested a return delegation: 'Seeing that the mother did not come, I proposed to your brother-in-law Gregorio to go to his house so that he would interview me with his wife, which seemed very good to him'. ${ }^{47}$

They all set off immediately. Crispina had been home late, and the house was not far, but they were surprised to find that in the time they had been away Crispina had gone to bed. Clearly she had expected no news worth waiting for to emerge from the visit to the presbytery. But the abbot had come to her. The family 'made her get up', but she did not feel obliged to be polite. She had said goodbye to Hildegard in 1928 when she was just Visitación's age, she had lived next door to the heroic heartbreak of

41 Catalan to Hildegard, 14 December 1949, NNA 01454/131.

42 Catalan to Hildegard, 14 December 1949.

43 Catalan to Visitación, 1 April 1949, NNA 01453/192.

44 Catalan to Hildegard, 14 December 1949.

45 Catalan to Hildegard, 14 December 1949.

46 Catalan to Hildegard, 14 December 1949.

47 Catalan to Hildegard, 14 December 1949. 
Matilde de la Fuente's family, and she had heard how Escolastica, six years in the Kimberley with Hildegard, had died slowly from consumption and overwork. Perhaps she had also heard the claims that had prompted the letter of reassurance from Felicitas. In any case, Crispina felt no need to learn any more about New Norcia from the abbot. The interview did not go as the others hoped: 'she was in a very bad humour and said I don't know how many things to me that were not very pleasant' ${ }^{48}$ She stormed against her daughter having any part of this mission, and Abbot Catalan retreated, hastily formulating a different plan:

I tried to calm her and left her, saying to her and to the others, that if in the end she changed her mind and gave permission to her daughter, that they should let me know quickly at Corella so that I do not take another girl, and that I would give preference to Visitación because she had kept her vocation to be a Benedictine missionary in Australia for some years. ${ }^{49}$

Crispina's gestures of resistance and the abbot's need to give an account to her sister make this letter a compelling archival nugget. But 60 years later Visitación does not want to hear; it is still fresh enough: 'You don't have to tell me. I was there.'. ${ }^{50}$

In the event, her mother's opposition softened. Hildegard wrote from the mission itself to persuade her sister to moderate her views, and her neighbour Paula, Matilde's mother, also talked it through. ${ }^{51}$ (Paula's voice would have carried weight: not only had she farewelled Matilde in 1928 but also her son Emiliano in 1948.) The mission's network encouraged Crispina to give her consent. Visitación and her father could advise the abbot she would make the journey.

Maria Villaño also encountered resistance. She too was drawn to New Norcia through a personal connection. Initially, following Scholastica Carrillo's swift departure for Australia in 1948, Maria had written to her friend in the new year of 1949, sharing her hopes of joining the mission herself. Scholastica shared the letter with the abbot, and three months later Catalan followed up with a letter to Maria. He was encouraging but asked her to consider her priorities clearly. Wanting to join her 'former

48 Catalan to Hildegard, 14 December 1949.

49 Catalan to Hildegard, 14 December 1949.

50 Visitación Cidad, Interview, Madrid, 26 October 2013.

51 Catalan to Hildegard, 14 December 1949; see also Catalan to Paula Amo, 13 January 1951, NNA 01456/86/118. 
good companion' would not be sufficient: 'your main motive ... must be to have time with the Benedictine Missionary Sisters for the good of souls and to help in all you can at the Mission. Look then at how much you really feel a vocation to be a religious and a missionary religious. ${ }^{52}$

Maria was already in serious conversation about the prospect of missionary work. She had answered concerns of her family that Australia was too far away with practical information supplied by the abbot: there was no rationing in Australia, and the novices were chealthy and have a lot to eat'. ${ }^{53}$ There were advisors in San Sebastian suggesting she should do a novitiate in Spain and then offer for the missions, but Catalan scoffed: 'life in the missions is so different you would be in danger of losing your vocation. ... [T] hey have no idea in San Sebastian about the Australian missions'. ${ }^{54}$ Instead, he suggested she visit the network in Burgos where New Norcia was well-known. Call on the Cistercians at Las Huelgas, Abbot Catalan advised, or the Benedictines of San José near the cathedral or the community at Palacios de Beneber. The abbot was pleased with her letter to Scholastica, 'I see a strong heart eager to do good according to the will of God', and told Maria to 'write to me quickly not worrying about expression, so that I may know if I may count on your vocation. ${ }^{55}$

By the end of the year Maria had left her job as a domestic in the fine house in San Sebastian, and the abbot was sending a parcel of fabric by registered mail to reach her in the village of Blandeande near Burgos so she could make the pleated black dress she needed (but could not otherwise afford) to travel as a postulant. ${ }^{56}$ In Maria's case, it was a relationship with someone who had already taken the step that made the difference; as the abbot observed: '[Scholastica], your good friend, has undoubtedly been the means God has used to prompt you to do the same thing. ${ }^{.57}$

This time, in good time, the abbot sent a photograph of the six to Sr Felicitas, 'good looking and I think of good spirit too', ${ }^{58}$ mixed in with details of finding the instruction book for the Alfa sewing machines that she had requested and the prospect of buying better fringing for

52 Catalan to Lucia (Maria) Villaño, 3 April 1949, NNA 01453/193.

53 Catalan to Lucia (Maria) Villaño, 3 April 1949.

54 Catalan to Lucia (Maria) Villaño, 3 April 1949.

55 Catalan to Lucia (Maria) Villaño, 3 April 1949.

56 Catalan to Teofilo Rojo, 12 December 1949, NNA 01453/87.

57 Catalan to Maria Villańo, 15 May 1949, NNA 10453/194.

58 Catalan to Felicitas, 23 November 1949, NNA 01453/127. 
a processional canopy once they got to Barcelona. The abbot told Hildegard the passports had been finalised; they would catch the Italian steamer Napoli from Genoa. He signed off cheerfully, sending equal 'greetings to Rosie and to all'59 at Bindoon, promising to call in to see them on their way to the mission. In his mind the journey was complete.

For the young women, the process of leaving with no intention to return was more taxing. There had been plenty to do in preparation, including a last-minute requirement for chest X-rays from an Australia fearful of tuberculosis, but Visitación was probably not the only daughter who knew her family still felt her leaving 'was like to bury me alive'. ${ }^{60}$ On the train to Barcelona they stopped themselves crying by singing, although 'we were still very sad and worried about our families'. ${ }^{61}$ In Barcelona they threw themselves into games with the children in the convent school where they stayed and then followed a whirlwind of sightseeing before travelling on to Genoa.

The departure from Italy was marked by confusion. Carmen Ruiz Besti remembers it as a frightening ordeal. Somehow, in the walk to the port the six were separated from the rest of the party. ${ }^{62}$ By the time they caught up, the others were on board, the passenger gangplank had been taken up, and the young women faced a ladder up the side of the ship. The water was a long way below the deck they had to climb to, and there was a crowd looking on. They were told the passenger door could not be opened again. Perhaps some in the party had been half-hoping they would miss the boat. Carmen, however, intended to sail:

Somebody had to go first. ... We saw the ladder, this is true, and one to another said, 'What! Oh no!' [It was] frightening to look at the water and to see ... fish jumping. We had to go up but [we said], 'You don't push me, because if you push me I'll drop in the water!' So one to another, the five of us, six of us, we go up.... [T] hey follow[ed] me. ${ }^{63}$

59 Catalan to Hildegard, 14 December 1949.

60 Visitación Cidad, Interview, Kalumburu, 24 April 1999.

61 Carmen Ruiz Besti, Interview, New Norcia, 28 July 1999.

62 Carmen Ruiz Besti, Interview, New Norcia, 28 July 1999.

63 Carmen Ruiz Besti, Interview, New Norcia, 28 July 1999. 
No one knows what the abbot and Fr Wilfrid had been thinking. As Carmen recalled it, once on board the women were allocated to their rooms and found the others on the deck. The rest of the journey was uneventful by comparison. They docked at Fremantle on Saturday 4 March and made their way to the monastery's house in Perth. ${ }^{64}$

The generous fig tree in the garden was the perfect backdrop for photographs to be taken for the families in Spain.

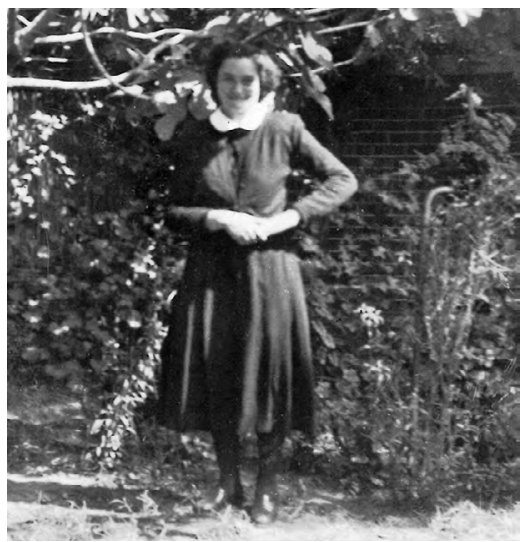

Figure 8.4: Visitación Cidad under the fig tree, Murray Street, Perth, 1950.

Source: ABTM.

Reflecting on the snapshot of her as a 19-year-old, Visitación mused on the mystery of a vocation: 'It is as Jesus said to Nathaniel, "Before another came to call you, I saw you under the fig tree". ${ }^{65}$ The biblical story speaks of the insight of Jesus and his capacity to see the truth of his disciples. It is a story that affirms the hallowed nature of a call: 'No, I did not think of it at the time, but I have often thought of it since'. ${ }^{66}$ In 1950, as they too were sung into the church at New Norcia in solemn procession, there was a new life to weave together with the hope or conviction that their choices were part of a deep and divine plan.

64 Sunday Times, 5 March 1950, 7, 24.

65 Visitación Cidad, Interview, Madrid, October 2013.

66 Visitación Cidad, Interview, Madrid, October 2013. For Nathaniel's call, see John 1:45-51. 
This text is taken from A Bridge Between: Spanish Benedictine Missionary Women in Australia, by Katharine Massam, published 2020 by ANU Press, The Australian National University, Canberra, Australia. 